\title{
PENGEMBANGAN AIR TERJUN SIKULIKAP DESA DOULU SEBAGAI OBJEK WISATA ANDALAN MASYARAKAT KABUPATEN KARO
}

\author{
Josephine Adelways Br. Purba, Ayu Dahniar Tampubolon, Irma Yefta W \\ Jurusan Pendidikan Geografi Fakultas Ilmu Sosial \\ Universitas Negeri Medan \\ Jl. Willem Iskandar Psr V Medan Estate Medan 20211, Indonesia \\ email : yosephineprb@gmail.com
}

\begin{abstract}
Abstrak
Kawasan wisata Air Terjun Sikulikap di Desa Doulu merupakan sebuah wisata barunya Sumatera Utara yang dalam tahap perintisan dan pengembangan. Sehingga banyak peluang untuk melakukan penelitian maupun dijadikan sebuah lokasi untuk kegiatan penelitian. Banyaknya potensi yang melimpah dari hasil alamnya, perikanannya, berbagai macam makanan khas dari Tanah Karo, dan masyarakat yang ramah serta mudah untuk diajak kerjasama. Tujuan penelitian ini untuk mengetahui Potensi wisata dan persepsi pengunjung tentang Sapta Air Terjun Sikulikap Di Desa Doulu, Kecamatan Berastagi Kabupaten Karo. Metode penelitian ini dianalisis dengan deskriftif kualitatif yaitu dengan menampilkan data dalam bentuk tabel-tabel frekuensi mengenai persepsi masyarakat mengenai objek wisata Air Terjun Sikulikap. Dengan adanya panorama alam yang indah dan suasana objek wisata yang memberikan kenyamanan yang dimiliki oleh objek wisata Air Terjun Sikulikap maka pengunjung tidak akan bosan dalam berkunjung. Sehingga tidak terpengaruh dengan munculnya objek wisata baru serta persaingan antar objek wisata. Maka pemerintah harus meningkatkan sarana dan prasarana serta infrastruktur yang menunjang dan peningkatan fasilitas-fasilitas penunjang lainnya sehingga menarik dan memberi kenyamanan bagi pengunjung.
\end{abstract}

Kata Kunci: Objek wisata, Air Terjun Sikulikap, Desa Doulu

\section{PENDAHULUAN}

Pariwisata merupakan industri yang kelangsungan hidupnya sangat peka terhadap kerusakan lingkungan oleh baikburuknya lingkungan (Soemarwoto, 2001). Industri ini sangat peka terhadap kerusakan lingkungan, misalnya pencemaran oleh limbah domestik dan kerusakan pemandangan alam, serta sikap penduduk yang tidak ramah. Suatu daerah wisata mempunyai kemampuan tertentu untuk menerima wisatawan, yaitu disebut daya dukung lingkungan. Daya dukung lingkunan di bidang pariwisata dapat dinyatakan dalam jumlah wisatawan per satuan luas per satuan waktu. Tetapi baik luas maupun waktu umumnya tidak dapat dirata-ratakan, karena penyebarannya wisatawan dalam ruang dan waktu tidak merata (Darsoprajitno,12:2002).

Kawasan wisata Air Terjun Sikulikap di Desa Doulu merupakan sebuah wisata barunya Sumatera Utara yang dalam tahap perintisan dan pengembangan (Humaira, 2015). Sehingga banyak peluang untuk melakukan penelitian maupun dijadikan sebuah lokasi untuk kegiatan penelitian. Banyaknya potensi yang melimpah dari hasil alamnya, perikanannya, berbagai macam makanan khas dari Tanah Karo, dan masyarakat yang ramah serta mudah untuk diajak kerjasama.

Wisata Air Terjun Sikulikap yang terletak di Desa Doulu, Kabupaten Karo, Sumatera Utara merupakan sebuah aset daerah yang berpotensi menjadi sebuah tujuan wisata yang cukup menjanjikan di Sumatera Utara (BPS, 2009). Prasyarat utama agar aset yang cukup berharga tersebut bisa menjadi sebuah komoditas daerah adalah dikelolanya tempat wisata tersebut dengan baik sesuai standar minimal industri pariwisata. Pengelolaan yang selama ini dilakukan oleh masyarakat setempat masih bersifat alami dan belum tersentuh oleh ilmu menajemen tata kelola sebuah industri wisata. Dengan kondisi tersebut, mencerminkan bahwa SDM dan SDA yang dimiliki masyarakat belum diberdayakan secara maksimal. 
Program Pengembangan Air Terjun Sikulikap di Penatapan Berastagi sebagai Objek Wisata Andalan Masyarakat Kabupaten Karo, pada dasarnya bertujuan untuk memaksimalkan peran masyarakat dalam mengelola potensi wilayah yang dimiliki menjadi sebuah aset yang bermakna. Kebermaknaan itu, akan tercapai jika seluruh potensi yang dimiliki masyarakat bisa diberdayakan lebih maksimal (Kementerian Pekerjaan Umum, 2016)

Desa Doulu juga memiliki daya dukung kekayaan alam yang sangat potensial, seperti padi, ketela, sayur-sayuran, buahbuahan, umbi-umbian dan kacangkacangan, apalagi daerah ini merupakan bagian dari kawasan pertanian sehingga sangat banyak hasil pertanian. Dengan potensi-potensi yang dimiliki tersebut diharapkan Wisata Alam Air Terjun Sikulikap di Desa Doulu dapat dikelola menjadi industri wisata kreatif yang memiliki ciri khas wisata organik yang saat ini diminati wisatawan.

\section{METODOLOGI}

Data dalam penelitian ini dianalisis dengan deskriftif kualitatif yaitu dengan menampilkan data dalam bentuk tabel-tabel frekuensi sehingga dapat mendeskripsikan kenyataan dilapangan. Pendekatan kualitatif melibatkan upaya penting seperti mengajukan pertanyaan dan prosedur, pengumpulan data dari partisipan, analisis data yang spesifik dari partisipan, analisis secara induktif, dan memaknai atau menafsirkan data (Cresswell, 2004)

Pengelolan dengan data kualitatif dilakukan untuk menilai sarana dan prasarana dan sapta pesona (Syahputra dkk, 2017). Skoring keadaan potensi obyek wisata Air Terjun Sikulikap menggunakan skala koordinat 1, 2, 3 untuk mengukur kriteria pada masing-masing indikator berkualitas buruk, sedang, dan baik (Arikunto, 2002).

Pengklasifikasian Berdasarkan Skor:
1. Skor 0 - 19: Kurang Baik

2. Skor 20 - 34: Baik

3. Skor $34-50$ : Sangat Baik

Peneliti melakukan pengamatan langsung ke lokasi sasaran untuk melihat secara langsung situasi kondisi yang sebenarnya. Observasi dilakukan terhadap potensi internal, potensi eksternal, prasarana, sarana wisata Air Terjun Sikulikap. Hasil observasi terhadap lokasi penelitian di berikan bobot 3, 2, 1 dalam kondisi baik, kurang baik, dan tidak baik.

\section{HASIL PENELITIAN}

\section{Air Terjun Sikulikap}

Lokasi Air Terjun Sikulikap berada di bawah Penatapan dengan merasakan air yang begitu dingin dan segar dari air terjun yang diapit oleh dinding bebatuan membuat wisatawan menyukai destinasi ini. Air terjun ini memiliki ketinggian sekitar 30 meter (BPS, 2016).

\section{Karakteristik Responden}

Responden dalam penelitian ini adalah pengunjung atau wisatawan lokal yang berkunjung ke Obyek Wisata Alam Air Terjun Sikulikap. Karakteristik responden merupakan bagian terpenting dari suatu penelitian karena dengan mengetahui karakteristik responden maka dapat diketahui obyek penelitian dengan lebih baik.

\section{Komposisi Responden Berdasarkan Cara} Melakukan Kunjungan

Berdasarkan data yang telah diperoleh, dapat disimpulkan bahwa kunjungan ke air terjun sikulikap cocok dilakukan dengan berkelompok dengan jumlah skor penilaian 15 , dan sebagian juga cocok jika dilakukan kunjungan bersama dengan rombongan keluarga dengan jumlah skor penilaian 10. Dapat disimpulkan juga bahwa melakukan perjalanan ke air terjun sikulikap cocok dilakukan secara berkelompok.

Tabel 1. Distribusi Responden berdasarkan cara melakukan kunjungan

\begin{tabular}{llcc}
\hline No. & Cara Melakukan Kunjungan & Jumlah (Orang) & Persentase (\%) \\
\hline 1 & Sendiri & 0 & 0 \\
\hline 2 & Berkelompok & 15 & 15 \\
\hline 3 & Rombongan Keluarga & 10 & 10 \\
\hline & Total & 25 & 25 \\
\hline
\end{tabular}


Pendapat Responden Mengenai Kondisi Jalan Menuju Obyek Wisata.

Berdasarkan data yang telah diolah dapat disimpulkan bahwa respon masyarakat terhadap kondisi jalan menuju air terjun sikulikap baik dengan jumlah skor penilaian 26, dan sebagian responden masyarakat kurang baik dengan jumlah skor penilaian 12.

Tabel 2. Penilaian Responden terhadap Kondisi Jalan

\begin{tabular}{clcc}
\hline No. & $\begin{array}{l}\text { Kondisi } \\
\text { Jalan }\end{array}$ & $\begin{array}{c}\text { Jumlah } \\
\text { (Orang) }\end{array}$ & Jumlah Skor \\
\hline 1 & Sangat Baik & 0 & 0 \\
\hline 2 & Baik & 13 & 26 \\
\hline 3 & Kurang Baik & 12 & 12 \\
\hline & Total & 25 & 38 \\
\hline & & & Sumber: Hasil Analisis, 2018
\end{tabular}

Pendapat Responden Mengenai Aksesibilitas Menuju Obyek Wisata

Berdasarkan data yang telah diolah dapat disimpulkan bahwa respon masyarakat terhadap aksesibilitas menuju air terjun sikulikap sangat mudah dengan jumlah skor penilaian 21 dan sebagian responden masyarakat mudah dengan jumlah skor penilaian 16, dan responden masyarakat sulit dengan jumlah skor penilaian 10. Dan aksebilitas ke air terjun sikulikap sangat mudah untuk dikunjungi. Kondisi diatas sesuai dengan pendapat Suwantoro (2002), yang mengatakan bahwa pembangunan prasarana wisata yang mempertimbangkan kondisi dan lokasi akan meningkatkan aksesibilitas suatu obyek wisata yang pada gilirannya akan meningkatkan daya tarik obyek wisata itu sendiri.

Tabel 3. Penilaian Responden terhadap Aksesibilitas

\begin{tabular}{llcc}
\hline NO. & $\begin{array}{c}\text { Tingkat } \\
\text { Aksesibilitas }\end{array}$ & $\begin{array}{c}\text { Jumlah } \\
\text { (Orang) }\end{array}$ & Jumlah Skor \\
\hline 1 & Sangat Mudah & 7 & 21 \\
\hline 2 & Mudah & 8 & 16 \\
\hline 3 & Sulit & 10 & 10 \\
\hline & Total & 25 & 47 \\
\hline
\end{tabular}

Pendapat Responden Mengenai Keindahan Alam Obyek Wisata

Berdasarkan data yang telah diolah, dapat disimpilkan bahwa respon masyarakat terhadap keindahan alam air terjun sikulikap indah dengan jumlah skor penilaian 30, dan sebagian responden

Tabel 4. Penilaian Responden terhadap Keindahan Alam

\begin{tabular}{clcc}
\hline NO. & \multicolumn{1}{c}{ Keindahan Alam } & $\begin{array}{c}\text { Jumlah } \\
\text { (Orang) }\end{array}$ & Jumlah Skor \\
\hline 1 & Sangat Indah & 8 & 24 \\
\hline 2 & Indah & 15 & 30 \\
\hline 3 & Kurang Indah & 2 & 2 \\
\hline & Total & 25 & 56 \\
\hline
\end{tabular}

Sumber: Hasil Analisis, 2018
Pendapat Responden Mengenai Sistem Tata Ruang dan Fasilitas Obyek Wisata

Berdasarkan data yang telah diolah dapat disimpulkan bahwa respon masyarakat terhadap sistem tata ruang Air Terjun Sikulikap adalah baik dengan jumlah masyarakat mengatakan sangat indah dengan jumlah skor penilaian 24 dan respon masyarakat kurang indah dengan jumlah skor penilaian 2. Dan dapat disimpulkan bahwa keindahan alam air terjun sikulikap yaitu indah.
22, dan sebagian respon skor penilaian 22, dan sebagian respon
masyarakat adalah kurang baik dengan jumlah skor penilaian 14. Dan dapat disimpulkan bahwa respon masyarakat mengenai sistem tata ruang Air Terjun Sikulikap adalah baik. 
Tabel 5. Penilaian Responden terhadap Aksesibilitas

\begin{tabular}{cccc}
\hline NO. & Sistem Tata Ruang & $\begin{array}{c}\text { Jumlah } \\
\text { (Orang) }\end{array}$ & Jumlah Skor \\
\hline 1 & Sangat Baik & 0 & 0 \\
\hline 2 & Baik & 11 & 22 \\
\hline 3 & Kurang Baik & 14 & 14 \\
\hline & Total & 25 & 36 \\
\hline & & & Sumber: Hasil Analisis, 2018
\end{tabular}

Berdasarkan data yang telah diolah dapat disimpulkan bahwa respon masyarakat terhadap fasilitas wisata Air Terjun Sikulikap lengkap dengan jumlah skro penilaian 18. Dan sebagian respon masyarakat menganai fasilitas wisata Air Terjun Sikulikap kurang legkap dengan jumlah skor penilaian 16. Dan dapat disimpulkan bahwa fasilitas wisata air terjun sikulikap yaitu lengkap.

Tabel 6. Penilaian Responden terhadap Fasilitas

\begin{tabular}{cccc}
\hline NO. & Fasilitas Wisata & Jumlah (Orang) & Jumlah Skor \\
\hline 1 & Sangat Lengkap & 0 & 0 \\
\hline 2 & Lengkap & 9 & 18 \\
\hline 3 & Kurang Lengkap & 16 & 16 \\
\hline Total & $\mathbf{2 5}$ & $\mathbf{3 4}$ \\
\hline & & Sumber: Hasil Analisis, 2018
\end{tabular}

\section{Pendapat Responden Mengenai Intensitas Kunjungan}

Tabel 7 menunjukkan bahwa Obyek Wisata Alam Air Terjun Sikulikap merupakan salah satu daerah tujuan wisata yang masih memiliki nilai daya tarik untuk dikunjungi. Beberapa responden yang telah melakukan 4 kali kunjungan dengan skor penilaian 16, dan sangat cocok untuk menjadi objek wisata bersama keluarga diantaranya memberikan alasan kadatangan disebabkan keindahan pemandangan alam hutan beserta karakteristik bentangan perbukitannya dengan hamparan pepohonan pinus dan hamparan persawahan serta tentunya menyaksikan karya sang Pencipta akan keindahan tumpahan Air Terjun Sikuliap tersebut dengan udara segar yang dapat dinikmati di kawasan ini.

Tabel 7. Penilaian Responden Intensitas Kunjungan

\begin{tabular}{lccc}
\hline NO & $\begin{array}{l}\text { Intensitas } \\
\text { Kunjungan }\end{array}$ & Jumlah (Orang) & $\begin{array}{c}\text { Jumlah } \\
\text { Skor }\end{array}$ \\
\hline 1 & 1 Kali & 9 & 9 \\
\hline 2 & 2 Kali & 5 & 10 \\
\hline 3 & 3 Kali & 5 & 15 \\
\hline 4 & 4 Kali & 4 & 16 \\
\hline 5 & $>4$ Kali & 2 & 10 \\
\hline & Total & 25 & 60 \\
\hline
\end{tabular}

Sumber: Hasil Analisis, 2018

Faktor - Faktor yang Menjadi Kekuatan Air Terjun Sikulikap

Berdasarkan pendapat pengunjung, lokasi wisata memiliki jarak yang terjangkau, akses menuju objek juga sangat mudah tidak seperti objek wisata air terjun lain pada umumnya, tiket masuk yang murah dan terjangkau, berbagai aktivitas yang bisa dilakukan di objek wisata adalah mandi, berfoto serta menikmati objek lain yang berdekatan berupa Pemandian Air Panas Sidebu-debu sehingga dalam satu kali kunjungan dapat menikmati objek dan aktivitas lainnya.

Pengelola lokasi wisata berpendapat bahwa pemandangan alam sekitar yang indah dengan hamparan sehingga menimbulkan kesan nyaman dan tenang tersedia lifeguard yang memantau keamanan dan keselamatan pengunjung, 
harga tiket terjangkau oleh semua kalangan baik pelajar maupun masyarakat umum.

Dari aspek penilaian masyarakat, pemandangan yang masih natural/alami menjadi daya tarik tersendiri bagi pengunjung dan lokasi yang mudah dijangkau dan dekat dengan objek wisata lain di Berastagi.

Faktor - Faktor yang Menjadi Kelemahan dari Air Terjun Sikulikap

Kurangnya fasilitas pengeras suara sebagai sarana informasi dan komunikasi bagi para guide kepada pengunjung, kamar mandi untuk ganti pakaian karena tidak tersedia kamar mandi dan cukup meghambat di saat kunjungan ramai, kebersihan areal masih kurang dan minimnya tempat sampah di beberapa titik menuju air terjun, jumlah tangga cukup banyak sehingga cukup melelahkan bagi pengunjung sehingga perlu disediakan pegangan

Selanjutnya, lahan parkir yang masih menyewa tanah dari pihak luar sehingga pengelola tidak punya keleluasaan mengelola tanah parkir, kesadaran pengunjung dalam menjaga kebersihan masih rendah serta kurangnya sistem pengelolaan sampah.

Selain kedua hal diatas, kebersihan yang masih rendah karena kurangnya kesadaran pengunjung untuk membuang sampah pada tempatnya merupakan factor yang masih lemah dari Air Terjun Sikulikap.

\section{Faktor - faktor yang menjadi peluang dalam pengembangan Objek wisata Air Terjun Sikulikap}

Kecenderungan jumlah kunjungan yang semakin meningkat dalam kurun waktu beberapa tahun terakhir merupakan peluang besar dalam pengembangan air terjun ini. Oleh sebab itu, pengelolaan yang optimal sangat perlu dilakukan untuk memberikan dampak yang positif terhadap kemajuan pariwisata di daerah ini.

Faktor - faktor yang menjadi ancaman dalam pengembangan daya tarik wisata Air Terjun Sikulika

Banyaknya objek wisata Air Terjun di Sumatera Utara yang memiliki karakteristik yang berbeda beda menjadi pilihan dan alternatif bagi pengunjung dan pecinta wisata alam, antara lain: Air Terjun Ponot, Air Terjun Sipiso-piso, Air Terjun Siguragura, Air Terjun Janji Bakkara, Air Terjun Sampuren Putih, dan Air Terjun Pelaruga.
Hal ini menjadi ancaman yang cukup besar apabila Air Terjun Sikulikap ini tidak dikelola dan dikembangkan dengan baik. Strategi Pengembangan Air Terjun Sikulikap sebagai daya tarik wisata alam :

1. Mempertahankan potensi alam yang natural dengan memasang tanda - tanda larangan untuk pencemaran dan sign untuk tidak membuang sampah sembarangan. Upaya lainnya adalah dengan menyediakan tempat sampah di beberapa titik pada objek wisata Air Terjun Sikulikap.

2. Mempertahankan tingkat kunjungan yang berkelanjutan dengan menjalin kerja sama dengan travel agent untuk mempromosikan objek wisata ini di kalangan wisatawan lokal dan mancanegara.

3. Berkoordinasi dengan berbagai pihak dalam mengelola dan mewujudkan pariwisata dengan membentuk kelompok sadar wisata untuk mewujudkan sapta pesona terutama meningkatkan kebersihan.

4. Melakukan penataan fasilitas pendukung antara lain warung makanan dan minuman serta membuat kamar mandi dan ruang ganti pakaian.

\section{KESIMPULAN DAN SARAN}

Adapun yang dapat disimpulkan dari penelitian ini adalah:

1. Dalam penelitian ini, faktor pendorong yang memperoleh kategori sangat tinggi adalah panorama alam yang indah, sejuk dan masih asli, sumber air yang melimpah serta suasana objek wisata yang memberikan kenyamanan bagi pengunjung objek wisata. Faktor penghambat yang memperoleh kategori sangat tinggi yaitu promosi objek wisata yang masih kurang dan keadaan yang kurang baik.

2. Dengan adanya panorama alam yang indah dan suasana objek wisata yang memberikan kenyamanan yang dimiliki oleh objek wisata Air Terjun Sikulikap maka pengunjung tidak akan bosan dalam berkunjung. Sehingga tidak terpengaruh dengan munculnya objek wisata baru serta persaingan 
antar objek wisata. Maka pemerintah harus meningkatkan sarana dan prasarana serta infrastruktur yang menunjang dan peningkatan fasilitas-fasilitas penunjang lainnya sehingga menarik dan memberi kenyamanan bagi pengunjung.

3. Perbaikan jalan yang rusak tentunya dapat memudahkan akses bagi pengunjung objek wisata Air Terjun Sikulikap, serta dengan adanya transportasi umum yang dapat digunakan pengunjung menuju objek wisata ini akan mampu menambah jumlah kunjungan ke objek wisata ini.

Beberapa hal yang dapat disarankan dari hasil penlitian ini adalah:

1. Pemerintah Kabupaten Karo perlu terus meningkatkan pelayanan publik di daerah wisata seperti kebersihan, kenyamanan, keamanan dan pelayanan sehingga dapat meningkatkan jumlah wisatawan. Karena saat ini fasilitas publik objek wisata Air Terjun Sikulikap kurang begitu baik. Selain itu jika jumlah wisatawan dapat meningkat dari tahun ke tahun maka diharapkan pendapatan pariwisata dapat meningkat juga. Namun pemerintah juga harus dapat mengoptimalkan agar pengeluaran yang di keluarkan tidak melebihi pendapatan yang masuk. Untuk menunjang pengembangan objek wisata, aksesibilitas menuju ke objek dan daya tarik wisata yang terdapat di objek wisata Air Terjun Sikulikap perlu ditingkatkan. Pemanfaatan teknologi informasi perlu ditingkatkan untuk mengenalkan dan mempromosikan potensipotensi wisata kepada masyarakat luas.

2. Untuk peneliti selanjutnya yang ingin melakukan penelitian di objek wisata Air Terjun Sikulikap disarankan melakukan penelitian dihari-hari libur karna lebih banyak yang berkunjung, seperti hari libur sekolah, hari raya dan libur lainnya.

\section{DAFTAR PUSTAKA}

Arikunto, Suharsimi. 2002. Prosedur Penelitian Suatu Praktek. Jakarta: Rineka Cipta

BPS. 2009. Kabupaten Karo dalam Angka. Badan Perencanaan Pembangunan Daerah Kabupaten Karo dan Badan Pusat Statistik Kabupaten Karo.

BPS. 2016. Kabupaten Karo dalam Angka. Badan Perencanaan Pembangunan Daerah Kabupaten Karo dan Badan Pusat Statistik Kabupaten Karo.

Creswell, J. W. (2010). Research design: pendekatan kualitatif, kuantitatif, dan mixed. Yogjakarta: PT Pustaka Pelajar

Darsoprajitno, S. 2002.Ekologi Pariwisata.Jakarta: Angkasa Offset.

Humaira, S. 2015. Air Terjun Sikulikap, Akses ke Sini Mudah Meski Lokasinya Tepat di Bawah Jurang Panatapan. http://www.tribunnews.com/travel/201 5/09/01/air-terjun-sikulikap-akses-kesini-mudah-meski-lokasinya-tepat-dibawah-jurang-panatapan.

Kementerian Pekerjaan Umum, 2016. Rencana Pembangunan Infrastruktur Terpadu Kawasan Strategis Pariwisata Pegunungan dan Budaya - Kawasan Berastagi. Pusat Pengembangan Kawasan Strategis Badan Pengembangan Infrastruktur Wilayah, Kementerian Pekerjaan Umum. Jakarta.

Syahputra, R. Silfeni, Abrian, Y. 2017. ANALISIS KEPUASAN WISATAWAN TENTANG PENERAPAN SAPTA PESONA DI OBJEK WISATA PANTAI AIR MANIS PADANG. Skripsi. Universitas Negeri Padang

Soemarwoto, O. 2001. Ekologi Lingkungan dan Pembangunan. Jakarta: Djambatan.

Suwantoro, G. 2002. Dasar-Dasar Pariwisata. Yogyakarta: Penerbit Andi. 